\title{
24 On the relation between science, culture, and language
}

\begin{abstract}
En la genèse d'une doctrine scientifique, il n'est pas de commencement absolu; si haut que l'on remonte la lignée des pensées qui ont préparé, suggéré, annoncé cette doctrine, on parvient toujours à des opinions qui, à leur tour ont été préparées, suggérées et annoncées. 'In the genesis of scientific doctrines, there is no absolute beginning; as far back as one may go in the line of thought that prepared, suggested, and announced a doctrine, one always arrives at opinions which, in turn, have again been prepared, suggested, and announced.'
\end{abstract}

Duhem (1913-1959: 1:5)

\$1 This final chapter will try to unite several of the many threads in this book. A first part will consider whether one can and should speak of science outside the Greek cultural horizon (\$§1-2). This leads to the point that methodology and scientific language develop in tandem for a culture on the brink of becoming scientific. Various forms of a language of nascent science from old cultures outside the Greek horizon (\$3) will be compared to Greek (\$4). The importing of the Greek kind of science into one of them - Latin - will then by highlighted and the main linguistic problems the translators faced discussed (§§5-8); they quite naturally led to a type of Latin similar to that of scholasticism (§9).

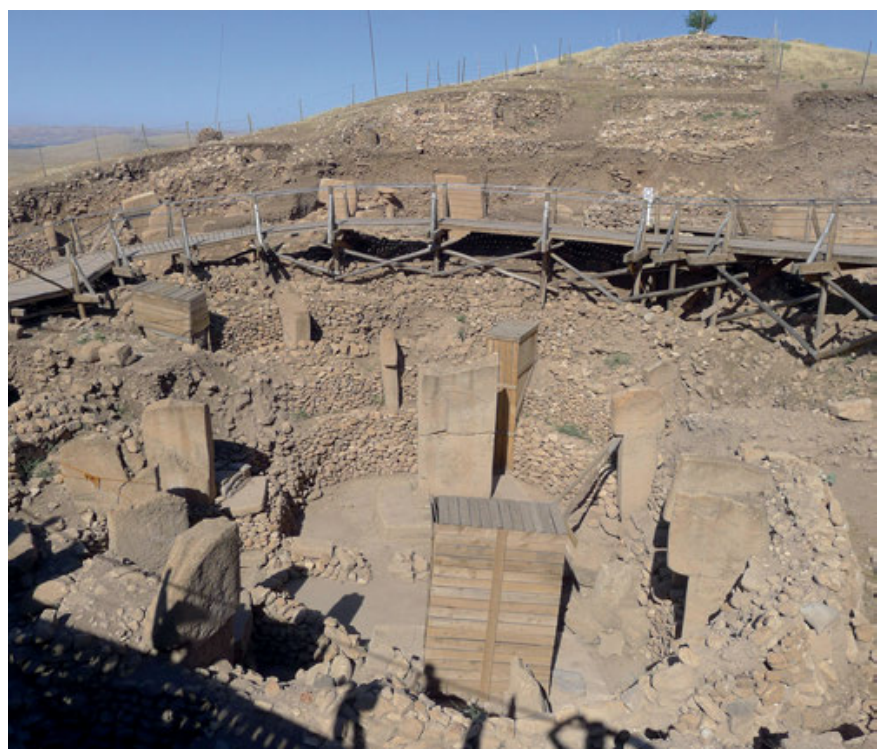

Fig. 49: Göbeklitepe site, near Urfa in Eastern Anatolia. The preserved, erected, and engraved stone pillars weigh up to 20 tonnes. Author's picture (2012). 


\section{Science a Greek invention?}

In order to embed the diaglossic study of the term 'science' and the proposed criteria for it (chap. 4) into a larger context, we consider the question of the origin of science. Even a cursory glance at the modern literature on this question will quickly lead to the impression that the answer to this question largely depends on one's definition of 'science'. Indeed, it has been shown in part 1 of this book how a notion of 'science' developed slowly over the past two and a half millennia in the Graeco-Latin world and what can pass as science and what cannot is still in flux today. Now, should one speak of science before the Greek authors studied above (chap. 7 §2-3)? We know of prominent feats of human material ingenuity since at least twelve thousand years ago, when the temple-like structure at Göbeklitepe ${ }^{1}$ (fig. 49) in Eastern Anatolia was built, for which the cooperation of a great number of people in an organised way was obviously necessary. Only for less than half the time span since then do we have written documents (since ca. 3000 BC in Sumer and Egypt), and for only about half of this time in turn is there cultural continuity in Europe (beginning in post-Dark Age Greece). ${ }^{2}$ In other words, insight complete enough for there to be a hope of tracing the relevant developments more or less adequately is available only for the past two and a half millennia. The development of human crafts, technology, philosophy, and stricter kinds of science was obviously a gradual process over the entire time span in question. If one sees science as a general problem-solving activity, ${ }^{3}$ then obviously it is much older than the Greeks. But it would seem that it makes sense to have several terms for such activities in this long time span of human mental development at one's disposal. Whereas the builders of Göbeklitepe certainly used 'craft' (ars), it is hardly appropriate to call what they had at their disposal 'technology' - a word that does, however, spring to mind in the case of the builders of the Egyptian pyramids in the first half of the third millennium BC. And theoretically minded 'science' consisting of feedback loops of unbiased observation and the search for underlying theoretical patterns (see chap. 4) is another matter again.

1 On this site, see Schmidt (2006).

2 Timeframes are comparable for China and India, the two other regions with written cultural continuity of a similar time-depth.

3 As, for example, D’Ooge (1926: 5-6) proposes in his translation of Nicomachos of Gerasa: not just 'the systematization of the sciences achieved by the Greeks, together with the process of logical demonstration' should be called science but instead science is taken as generally concerned with 'problems involved in comprehending the universe'. This approach is common among French authors as well, where the word science covers both 'science' and 'knowledge'. More examples were quoted in chap. $4 \S 3$ above. 
Now, given that we possess quite extensive information about Mesopotamian and Egyptian technical writing, it can be compared to the Greek kind of science that developed between the sixth and fourth centuries (discussed in chap. 7). Among scholars of Mesopotamia, the point of view that Mesopotamian culture, despite cultivating many skills in many of what would later become scientific disciplines, must be termed 'pre-scientific' still seems to prevail; ${ }^{4}$ the reason for this is that it did not try to understand systematically and methodologically the phenomena that are often meticulously described. Thus, the initial euphoria about pre-Greek science expressed, for example, by Paul Schnabel (1923) had to be put into perspective. ${ }^{5}$ Mesopotamian 'mathematics' was more than mere calculating; it can be described as algorithmic in concrete number examples, leading to a quite advanced art of calculation. A kind of oracular and etymological 'science' evolved from the polysemy of the cuneiform script, ${ }^{6}$ and a similar search for hidden meaning in the stars led to astrology, for which rather 'scientific' astronomical tables were prepared. In general, people have referred to Listenwissenschaft ('science in the form of lists') in the ancient Orient (since Soden 1936). All of these branches akin to science were already flourishing around 2000 BC. ${ }^{7}$ Similar points could be raised for ancient Egypt, especially in its Wissenschaft des Jenseits ('science of the beyond'), meticulously describing the topography of the next life. ${ }^{8}$

It is now beyond doubt that the Greeks acquired a lot of practical and technical knowledge from the Mesopotamian and Egyptian cultures, but it seems that both lacked rigorous, theoretical, methodological approaches subjecting their knowledge to unbiased testing. ${ }^{9}$ Thus, the Babylonian art of calculating lacked the

4 Neugebauer: 'Babylonian mathematics never transgressed the threshold of pre-scientific thought' (1970: 48). Similarly van der Waerden (1954-1974, 1966). New findings may, of course, change this conclusion. More recent publications seem rather to avoid such 'metaphysical' questions.

5 Discussed in Hunger \& Pingree (1999).

6 See Bottéro (1987); for example, he speaks of 'la “dialectique” graphique' (180-194). By the way, a similar dialectic still exists in the Chinese writing system today.

7 A good overview of technology, culture, magic, medicine, calculating, the status of writing, books, libraries, and many other things in Egypt (section 1) and the ancient Near East (section 3) is provided in Petruccioli (2001-2004:vol. 1). Unfortunately, the question of what science is, is avoided in this work.

8 Hermsen (1991: 31). See further the collection of important sources in translation in Clagett (1989-1999).

9 As Crombie (1996: 440) puts it: 'In Western terms they [cultures before and alongside the Greeks] had no system of rational science.' Clagett (1955: 19-20) had already reached similar conclusions, but his statement that '[a] history of science of this [pre-Greek] period clearly confirms the empirical origin of science' rather puts the cart before the horse - at least if one agrees to see science as the interplay between 'theory' and 'empiricism'. 
idea of proof ${ }^{10}$ and used no general, theoretical formulations. ${ }^{11}$ More theoretical Mesopotamian texts do appear, but only in the last two centuries before Alexander, thus in the same timeframe as in Greece. ${ }^{12}$ Unfortunately, and despite the great advances achieved by West and Burkert in the past few decades, ${ }^{13}$ our knowledge about the Greeks' debt to their predecessors is still rather sketchy, making it hard to gauge what we are to expect early Greek thinkers in Asia Minor (such as Thales and his disciples) to have learned from Assyrian and other Mesopotamian lore. In some cases, men who may have served as links between the Orient and Greece can still be traced - for instance, the Greek physician Democedes of Croton, who worked at the Persian court in the sixth century. ${ }^{14}$ But above (chap. 7 §2), it became clear that we should also consider these earliest Greek 'pre-Socratics' as pre-scientific, and that we could trace the accumulation of the necessary ingredients for 'science' in fifth-century Greece quite well, but not earlier.

\$2 Some of these ingredients of scientific endeavour seem to be human universals, for instance the desire to produce elaborate classification schemes for the things in one's surroundings (Listenwissenschaft). ${ }^{15}$ In ancient cultures, one also commonly finds the phenomenon of the 'wise man' who tells other people 'the truth' he has received by some special faculties available only to a few chosen men like him. The Milesian philosophers with their fanciful and apodictically formulated cosmologies that are often completely incompatible with one another are good examples. A little later Empedocles, who claims to be of divine origin, ${ }^{16}$ or Heraclitus, who speaks in riddled aphorisms, are further examples of typical behaviour of wise and divinely inspired men. ${ }^{17}$ Ancient India knows similar sages in

10 Lloyd (1979: 230).

11 Lloyd (1987: 44) rightly adds that the Greeks tend to overdo it: 'they often, it may seem to us, fail to recognise the limitations of what they had achieved or of what they could hope to achieve, [...] the answers they proposed are vulnerable, if in different ways, to criticisms similar to those they themselves brought against earlier beliefs.'

12 Examples in Hunger \& Pingree (1999: 203-212). Several late Babylonian astronomers are mentioned by Strabo (Geographica XVI.1.6, ed. Radt, vol. 4, p. 282). Allen (1989) develops an idea voiced by Assmann: that Akhenaten's (d. 1336 or 1334 BC) new Sun-religion would rather have developed into a kind of pre-Socratic study of nature than into monotheism, had it been successful. 13 Especially West 1997 and Burkert 2004.

14 Herodotus, Historiae III.131-138, ed. Wilson, vol. 1, pp. 317-322. Doubt has recently been cast on the historical existence of Democedes (Davies 2010).

15 On which see Lévi-Strauss (1962: esp. chap. 5). See §3 below on Chinese 'correlative thinking’.

16 Frag. D4 LM, line 4 = B112 DK.

17 See Meuli (1935) and his comparison of these wise men to Siberian shamans (see chap. 7 §2 above). Lloyd (1987: 87) presents literature on sages in the ancient Near East and India, contrasting the exoteric nature of wisdom in Greece. 
the early Upanishads, which, incidentally, seem to have been composed about the same time those early Greek thinkers flourished. Unfortunately, close to nothing can now be traced about individual thinkers among them, though they are often mentioned by name. In China, Confucius (551-479 BC) and 'Laozi' (the presumed writer of the Dàodé jīng 道德经) could similarly be compared with the pre-Socratic philosophers. It would seem that philosophy tended to evolve out of such wise men's lore in various cultures; in contrast to science and although the term 'philosophy' itself is typically Greek, it does make sense to speak of Indian or Chinese philosophy before contact with the Greeks. ${ }^{18}$ As Lloyd (1987: 49) stressed of the early Greek philosophers, they

were wise men of a different kind, unlike the old seers in important respects, though again much closer to them in others than aspects of the self-image they projected would lead one to expect. ${ }^{19}$

It has been described how Plato and Aristotle strove to make the word غ̇лıбтn $\mu \eta$ mean an especially rigid and certain kind of knowledge (chap. 7), one that knows the 'why', not only the 'how', of something. Already before them, some authors started to do what would become science, and after them in Hellenistic times, sciences like geometry, astronomy, zoology, botany, and textual criticism and their inventors are for the first time clearly discernible. As Schadewaldt (1960: 871) put it:

Man könnte es, von der übrigen damaligen Welt her betrachtet, vielleicht eine Marotte nennen, was diese Menschen, vor allem vom sechsten Jahrhundert v. Chr. an, trieb und bewegte, eine Marotte freilich von weltumwälzender Bedeutung. Da versteiften sich diese Männer darauf, zunächst und zuvörderst nicht so sehr vom Bedürfnis und den praktischen Zwecken auszugehen (die auch sie recht gut zu verfolgen wußten), sondern sich zunächst und zuvörderst einmal sich für die Sache selbst zu interessieren, für das Es selbst der Dinge auf allen Gebieten: z.B. nicht bloß zu zählen und zu rechnen, um etwas zusammenzuzählen und auszurechnen, sondern deswegen, weil hinter dem Rechnen und dem Zählen das überaus interessante 'Es selbst' der Zahl steht, was weiterhin zur Mathematik führt. Und so auf allen anderen Gebieten von Natur und Gesellschaft [...].

'Looked at from the point of view of the rest of the world at that time, one could perhaps call what drove and moved these people, especially from the sixth century BC, a whim - a whim, admittedly, of world-shaking importance. These men insisted, first and foremost, on being

18 Treated e.g. by Zimmer (1969) for India and Mou (2009) for China. Possible terms in these languages for 'philosophy' are (tattva)vidyā ('(essential) knowledge') in Sanskrit and 哲 zhé ('wisdom’) in Chinese. Contemporary Chinese uses 哲学 zhéxué to translate our 'philosophy’. See §3 below for more on 学.

19 He further points out that theirs 'was a wisdom committed to different procedures of discovery and of the justification of belief' (Lloyd 1987: 335). 
not so much interested in the needs and the practical purposes (which they knew how to pursue quite well), but rather in the thing itself, in the "per se" of things in all fields, for example not only counting and calculating in order to add up and calculate something, but because behind the calculation and the counting there is the extremely interesting "per se" of number, which leads to mathematics. And so too in all other areas of nature and society [...].'

In the same vein Lloyd (1979: 224) stated:

We saw [...] that much of the strength of Greek science lies in its formal dialectical and demonstrative techniques, and that the definition and analysis of the axiomatic, deductive system, together with the development of the application of mathematics to the understanding of natural phenomena, occupied a considerable and productive intellectual effort.

But, it has also became clear (see chap. 3) that there was no unambiguous term for 'science' yet; the less strict meanings of غ̇лıбท' $\mu \eta$ and scientia remained in use in both ancient languages. English and German today would differentiate the two meanings as 'knowledge' (Wissen, Erkenntnis) vs 'science' (Wissenschaft). The development of a concept 'science' was followed in outline in part 2 of this book; by the mid-twelfth century the Aristotelian conception of science had become generally known as scientia in Latin Europe, from which our understanding of 'science' follows organically. ${ }^{20}$ Thus, the motto quotation by Duhem remains valid, although this does not mean that we should refrain from trying to conceptually structure the continuum of developing thought. It is obvious that the origin of science cannot be found in one single event (Lloyd 1979: 231); several factors together, most of which also occurred elsewhere, had to be combined in the time of Plato's Academy and especially in Aristotle's own school for a scientific frame of mind or Denkstil to establish itself definitively. These factors are what we tried to list as criteria for science above (chap. 4). Especially relevant for the beginnings are rigorous and conscious use of language (leading to the science of logic); the idea of proof, itself based on logic and mathematics (which therefore had to exist at least in nuce before); the necessity of a method in principle comprehensible to anyone; ${ }^{21}$ critical examination of new theories (although many early Greek thinkers - including Aristotle - were better at this when dealing with their opponents' theories than with their own); and the gathering or observing of facts to be used in a coherent manner. As has been seen above, in the fifth century ${ }^{22}$ a considerable

20 It had done this already several centuries earlier in Arabic as 'ilm.

21 Termed 'self-conscious methodology' by Lloyd (1979: 233).

22 The question of why this 'scientific spirit' developed precisely in fifth-century Greece is discussed at some length in Lloyd (1979: esp. 236-264), and again in Lloyd (2000), who considers sociological factors that separate classical Greece from other early cultures, especially public debate (11), and in general political and social conditions. A society's openness to and appreciation of in- 
body of new knowledge in astronomy, geometry, and other future scientific fields accumulated. Besides, written records available to a large community facilitated the growth of science significantly, although this does not seem to be a conditio sine qua non. ${ }^{23}$ We will now compare some cultures outside the Greek horizon and their approaches to learning, scholarship, and technology.

\section{Nascent science outside the Greek cultural horizon}

\$3 In Hellenistic times, this Greek scientific frame of mind seems to reach a 'critical mass' in society. It spreads throughout the Greek-speaking world and produces the beginnings of many sciences and hand-in-hand with them often also technological advances. It will also spread to other cultures that come in contact with those Greeks. The Arabs and Latins of later times are the best-known and most fruitful examples. In contrast, cases of similarly scientific endeavours outside the reach of Greek culture are hard to find; indeed, the interplay of observation and pattern-seeking so typical for science is found at best in nuce. The most promising such cultures are the Chinese and the Indian ones, the latter before extensive contact with the Greeks after Alexander the Great's campaign. As mentioned, early (pre-Han) China certainly had its share of wise men, who in some cases rather strongly resemble their Greek and Indian counterparts. ${ }^{24}$ In China we find technical texts on various topics, works on statecraft, philosophical disputations, or 'mathematics'. There was even an institution with the potential to become a scientific school, the Jixià academy (稷下学宫) in the state of Qí (齊) in present-day Shandong province, which operated during several generations but ended in 221 BC when Qí was conquered by Qín (秦). Not much is known about the institution itself, but it is clear that scholars from other Chinese states also met there to discuss and that there was Qi state patronage. ${ }^{25}$ Famous intellectuals frequented it, such as Mencius, Xun Zi, and Zou Yan, who had the clearest interest in 'nature' among them. Instead of science, what has been called 'correlative think-

novation is certainly also important; in Greece there was a minor literary genre on the $\pi \rho \tilde{\omega} \tau o \varsigma ~ \varepsilon \dot{v}$ -

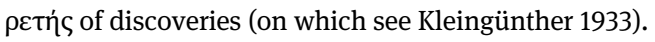

23 Indian grammarians were able to do without it. Pāninini developed his scientific grammar apparently without writing it down (writing was not yet in use in India at that time) and handed it down among his pupils by having them memorise it. Thus, the argument one encounters occasionally, that science needs literacy, is not strictly true.

24 For an introduction, see Harper (1999), especially on Mohist 'science' (813) and on recently rediscovered technical manuscripts from the Warring States period (475-221 BC; 819). See Levi (1988) on Chinese pre-Han 'sophists'.

25 See Nivison (1999: 769-770). 
ing' evolved from these early Chinese intellectual currents: yīn vs yáng (陰陽) and the five 'elements' (wǔxing 五行), leading to a school founded by Zou Yan, ${ }^{26}$ sometimes questionably labelled the 'School of Naturalists' but more correctly that of Yin-yang (Yìnyángjiā 阴阳家). Typically, lists of correspondences, for instance of elements, colours, and rulers, are made that resemble Western hermeticism (chap. 12 §5). Nivison (1999: 810) concludes:

[c]orrelative thinking seems scientific but is actually close to the intuitive aesthetics of music and dance; it tended to crowd out any possibility of a vigorous development of genuine science in ancient China.

Among the more technical 'sciences', the art of calculation was quite developed at least by early Han times (202 BC-AD 220), as demonstrated by works like the Nine Chapters (Jiǔzhāng suànshù 九章算术). ${ }^{27}$ But they again lack the idea of proof and rather resemble the Mesopotamian 'mathematics' discussed above (\$1). China clearly had its indigenous kind of learning, but little of traditional Chinese learning that has survived to modernity (Chinese medicine, fēngshul̆, the yìjing, ...) would be recognised as scientific by modern scientists, hardly even as remote predecessors of science.

In Chinese, 'science' can be addressed as xué shù, a term made of xué (学 'learning, knowledge, art'), whose basic meaning 'to learn' resembles doctrina (1.3 §8), and shù (术 'method, technique, art, systematic learning', a character related to 行 xíng, 'go, move, perform'). The term can be compared to Roman disciplina (1.3 §3); either of these two characters can also be used individually with a similar meaning. Further combinations confirm that the meaning is broader than our 'sciences', for example 魔术 móshù ('magic', literally the 'art of demons'), or 文学 wénxué ('literature', literally 'language learning'). The modern Chinese term for 'sciences', kēxué (科学 'branches of learning'), stems from the nineteenth century and was formed in imitation of Western 'science' and adds the character 科 $k \bar{e}$ ('division'), thus emphasising the edifice of scientific fields. ${ }^{28}$

India also developed some 'sciences' before sustained contact with the Greeks, most notably grammar/linguistics - Pāṇini’s (probably fifth century BC) grammar reached a level of understanding of the structures of language that the

26 Unfortunately, his works are lost. Our best source is the Han historian Sima Qian.

27 Specialists see them as home-grown, thus unrelated to Greek mathematics. Edition: Chemla \& Shuchun (2004). On Chinese mathematics in general, see Martzloff (1988).

28 See Wang Hui (2011: 46-47). Lloyd \& Sivin (2002) compare Greek and Chinese conceptions of 'science'. For an encyclopaedic history of science in China, see Chemla (2001). Kim (1982) explores why premodern China did not have a 'Scientific Revolution'. 
West did not reach before the nineteenth century ${ }^{29}$ - and other 'sciences' in the context of ritual and holy texts. Very little is known about Pānini or his way of working and of forming a school of thought that would hand down his grammar. We know that he was active in Salātura in Gandhāra (some eighty kilometres north-west of Islamabad, at least nominally part of the Persian Empire then). ${ }^{30}$ The closest Sanskrit equivalent for 'science' is śāstra (neuter), but it has a much broader range of meanings, including 'precept, rule, teaching, manual, compendium, religious or scientific treatise ${ }^{31}$ - also somewhat similarly to Latin disciplina. This word is used to designate all sciences (in the broad sense of Wissenschaft) from around the turn of the Christian era. ${ }^{32}$ It is derived from V'sas ('instruct, command, punish', of unclear further kin). India's early sciences apparently evolved from the pursuit of ritual, which is for its systematic nature called 'ritualistic science' by Staal (1996: 349-367); it is debated since when exactly ancient India also knew of such 'sciences' as dharma-śāstra (the study of law), artha-śāstra (the study of worldly life, roughly 'political science'), kāma-śāstra (the study of sex), and śilpi-śāstra (the study of mechanical arts). ${ }^{33}$ In most cases, it is unlikely that these Indian branches of learning pre-date Alexander the Great and thus intense contact with the Greeks, but it is certain that Pānini did.

If the foundation of śästra is taken to lie in ritual, and that of xué in Chinese correlative learning, we might say that śāstra and xué were hardly developed out-

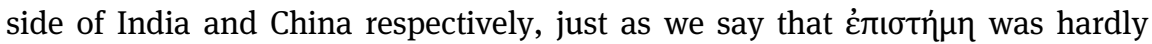
developed outside of the Greek cultural horizon. ${ }^{34}$ The decisive difference is, of course, that غ̇лıбท́ $\mu$-scientia-'science' and its technology have turned the world upside down (for good and for ill) and become the international standard approach. Indian and Chinese scientists and engineers today study, teach, and apply modern, that is, Greek-based science like everybody else. The relationship between the concepts غ́лıбтn் , sāstra, and xué would be a rewarding topic to study more closely in order to see to what extent the meaning of these terms developed independently and convergingly. This is made difficult by the dearth of

29 On Indian grammar and linguistics, see Cardona (2001).

30 See Scharfe (1977: 88-89).

31 The meanings are given in shortened form from Monier-Williams (s.v.).

32 Thus Staal (2001: 615). The science of sciences (śāstra śāstrānam) in ancient India is linguistics.

33 For a summary of some of the text, compare Winternitz (1909-1920: vol. 3). See in addition Gonda (1973-1987), esp. Scharfe (1977) on grammar.

34 As Burnet (1920: v) puts it: 'It is an adequate description of science to say that it is thinking about the world in the Greek way. That is why science has never existed except among peoples who have come under the influence of Greece.' 
early sources and by the intense contact that has existed between these three Euro-Asian cultural spheres for at least two and a half millennia.

A look at the language of the clearest case of science outside the Greek horizon may help to understand the relation between science, culture, and language better. Pāninin's grammar is written in sūtra or aphoristic style. For instance, he says (Aștāâdhyāyī I.4.101-102, ed. Boehtlingk, p. 42):

\section{tinas trịni trīṇi prathamamadhyamottamāḥ |}

tāny ekavacanadvivacanabahuvacanāny ekaśạ̣ //

'The three times three conjugational affixes [tim] are third person, second person, first person;

the latter [are] individually [called] singular, dual, and plural.,35

In short, this specifies that there are three persons and three numeri for any Sanskrit verb, as swell as their names. The 'scientific' (i.e. strictly valid) part of the science is formulated in a very strict manner, comparable to mathematical formulas. For non-experts, it takes a teacher or commentary literature to understand it. $^{36}$ This will remind the reader of the one Latin candidate discipline that largely developed more or less outside the Greek sciences: Roman law. We saw (chap. 7 $\S 3)$ how statements were compressed in the Twelve Tables:

Si in ius uocat, ito; ni it, antestamino; igitur im capito.

'If someone calls to court, one must go. If not, a witness is to be taken. Thus he is to be seized.'

This formulation could also be termed aphoristic: statements are brief, the syntax is simple, and indeed the persons involved often have to be adduced from the context. The language of the later jurists (chap. 7 \$12) is much more complex; its logical structure (as that of Classical Latin in general) will be influenced by Greek logic and rhetoric. A text like the Twelve Tables requires external explanation by professionals. Indeed, in later times the Tables were often treated by jurists in commentaries; these lost commentaries can be suspected to have been modelled on Helle-

35 Thus a literal translation. An explanatory one would be much longer and might look like this: 'The three triads in both the sets Parasmaipada and Atmanepada, of conjugational affixes (comprised under the general name tin, a pratyâhâra formed of the first and last of them, viz., tip and mahin) are called, in order, lowest (3rd person of European Grammar), the middle (2nd person), and the highest (1st person). These three triads of conjugational affixes, which have received the name of Lowest \&c., are called (as regard the three expressions in each triad) severally "the expression for one" (singular), "the expression for two" (dual), and "the expression for many" (plural)' (http://panini.phil.hhu.de; project leader: Wiebke Pedersen).

36 Details from Cardona (2001: 743-752). 
nistic commentary literature. The same happened to (and preserved) Pāṇini's grammar: we have written commentaries since at least Kātyāyana (second century $\mathrm{BC}$ ). Some early Greek 'scientific' texts also resemble these two aphoristic examples, for instance those by Heraclitus or Empedocles. However, Classical and Hellenistic Greek science texts, in contrast, are usually in themselves understandable to the reader: thoughts are logically developed in detail. They were based on a relatively broad educated reading public - beyond a narrow and secretive school interested in them. The decisive 'critical mass' for Greek science becoming a phenomenon of sufficiently wide interest to keep being cultivated and handed down accumulated in Hellenistic times. Later cultures, most notably the Arabs and the high mediaeval Latins, were able to take up this scientific Greek approach, which finally led to our modern science. A similar development could in theory also have happened in other cultures, outside the Greek cultural horizon, but it did not.

\section{Linguistic structure of Greek science}

\$4 Now, how did the scientific Greek language we know from authors such as Aristotle and Euclid evolve? Above (chap. 4 §), we proposed as characteristics of scientific language: (i) well-defined terminology, (ii) exactness and univocity, (iii) extendability and flexibility, (iv) perspicuity, (v) evidentiality and modality. Point (i) requires methodical thinking about language (as the sophists, Socrates, Plato, and decisively Aristotle did; see chap. 7); points (ii) and (iii) profit from a large and logically extendable vocabulary; points (iv) and (v) from clear syntax. Past scholarship, especially the German classical philologist Bruno Snell, stressed such characteristics as typical of the Greek language, thus predetermining Greek to become a vehicle of scientific thought. Snell (1946: 199) said: ${ }^{37}$

Es ist [...] nicht abzusehen, wie in Griechenland Naturwissenschaft und Philosophie hätten entstehen können, wäre nicht im Griechischen der bestimmte Artikel vorhanden gewesen. [...] wie hätte man etwas Adjektivisches oder Verbales begrifflich fixieren können, wenn der

37 Snell's approach toward the Greek Entdeckung des Geistes has been very fruitful in German classical philology but has also been heavily criticised. Burkert discusses the situation lucidly (2001-2011: 8:277-292), concluding that much in Snell is strongly exaggerated due to his lack of acquaintance with the ancient Orient. Burkert in his review, on the other hand, would seem to similarly go too far in another direction by stating his rejection of concepts such as Seele and Geist. Apparently, Neugebauer (285) told him that he preferred Babylonian 'true' mathematics to the Greeks' tendency to mystify everything. As pointed out above (\$1, quoting from Neugebauer), what the Babylonians did was studying the practical art of calculation, not apodictic mathematics (invented by the Greeks). This is a difference that is still crucial in university mathematics today. 
bestimmte Artikel nicht die Möglichkeit geboten hätte, solche 'Abstraktionen’ wie wir sagen, zu bilden?

'It is [...] hard to see how science and philosophy could have come into being in Greece if the definite article had not been available in Greek. [...] how could something adjectival or verbal have been conceptualised if the definite article had not offered the possibility of forming such “abstractions”, as we say?'

We have seen above (chaps 21-23) that many a language can learn to express nearly anything in science, given the urge to do so and sufficient time. Nonetheless, it seems obvious that some languages have a long way to go to become vehicles of scientific communications - think of a language that has no words for numbers or no clearly defined subordination - whereas others can combine their own and foreign elements quite effortlessly. Today, every major language has been engineered to be able to express Western (i.e. Graeco-Latin) scientific thought to a large degree. Nonetheless, Snell certainly correctly observed the importance of certain features of the Greek language used by early Greek scientists, especially effortless compounding, easy and versatile creation of noun phrases with the article, and the creation of new but intuitively understandable words by pre- and suffixation. ${ }^{38}$ Chapter 22 showed some of the difficulties Arabic and Latin had in adopting such traits when translating Greek science. As we live in a world colonised by Western technology and worldviews, the gap has become much smaller, and it may even be difficult today to imagine the difficulties Arabic or Latin translators grappled with when trying to import Greek scientific thought into their respective languages for the first time in the Middle Ages. Indeed, Latin scientific authors often complain about Latin's perceived inferiority compared to Greek, for instance Kepler on the missing article (Astronomia nova, ed. Frisch, p. 146):

Durissima est hodie conditio scribendi libros mathematicos, praecipue astronomicos. Nisi enim servaveris genuinam subtilitatem propositionum, instructionum, demonstrationum, conclusionum, liber non erit mathematicus; sin autem servaveris, lectio efficitur morosissima, praesertim in latina lingua, quae caret articulis et illa gratia, quam habet Graeca, cum per signa literaria loquitur. Adeoque hodie perquam pauci sunt lectores idonei: ceteri in commune respuunt. 'The conditions for writing books in the mathematical sciences are very hard today, especially astronomical ones. If you do not keep to the subtleties of propositions, doctrines, demonstrations, conclusions, the book will not be mathematical. But if you do, it will become extremely tedious reading, especially in the Latin language, which lacks articles, and that grace Greek has when it speaks with alphabetical variables. And besides, these days there are very few suitable readers; the others commonly reject it. 39

38 More details on these matters in Roelli (2018) and below.

39 Litterarius, 2: 'alphabetisch' (Ramminger, s.v.; consulted 6 December 2018). Kepler alludes to the Euclidean usage of addressing for instance a line as $\dot{\eta} A B$, which could be declined easily in Greek but not at all in Latin. 
The fact that Latin cannot decline letter symbols, which works so nicely for Euclid, was clearly especially painful to mathematicians. Of course, care has to be taken that such evaluations of the 'fitness' of languages for certain purposes do not become mere language ideology, something very common in the time when Latin's heirs were quarrelling for supremacy. ${ }^{40}$ Examples of authors 'proving' the inherent superiority of French (such as Joachim Périon), ${ }^{41}$ German (such as Georg Friedrich Meier or Gottfried Wilhelm Leibniz), ${ }^{42}$ or even Dutch (such as Simon Stevinus) ${ }^{43}$ could be quoted. But the naturally occurring features of the Greek language certainly came in very handy for the expression of novel ideas by early Greek philosophers and scientists. We shall now take a closer look at what Latin authors did when importing Greek scientific thought.

\section{The import of Greek science into Latin and modern science}

\$5 The influx of Greek ideas, and with them of linguistic adaptations into scientific Latin, has been seen in part 2 of this book to have happened in five stages (one of them a dead end). ${ }^{44}$ In Classical Antiquity (i), philosophers such as Cicero and Seneca made Latin prose capable of expressing philosophical (mostly Stoic) or doxographic thought from Greek, although largely excluding Aristotelian scientific thought and terminology (such approaches continued to be practised exclusively in their 'native' medium, Greek). At the end of Antiquity (ii), Boethius tried to change this, and succeeded for logic (his translations of the Organon were used in schools all through the Middle Ages), but did not have time to tackle natural philosophy. During the Carolingian renewal (iii), John Scotus Eriugena's lonely attempt to incorporate Greek (neo-Platonic) thought into Latin thinking was of very limited success. Only the fourth (iv) and far wider attempt of the translation movement in the twelfth century, when the work was shared by many and spread across several centres, succeeded; it led to thirteenth-century scholasticism, which was heavily indebted to Aristotelian methodology and the translators' language. The last stage (v), in the time of the Renaissance, is different from the mediaeval ones in that many authors were again becoming directly acquainted with

40 Language ideology concerning the biblical languages during Baroque times has been studied by Roelcke (2014).

41 Périon (2003), linking it to Greek.

42 Meier (1763); Leibniz (1872c), discussed in chap. $11 \S 6$ above. See further Strassner (1995).

43 A mathematician who purposefully wrote many of his works in Dutch and often invented new terminology on the way; see van der Wal (2004).

44 Excluding important influence in other areas, especially crucially in the Latin Church Fathers, whose Christian Latin is heavily indebted to Greek. 
Greek, and many of them could and did actively read Greek works, as intellectuals did in Antiquity. But unlike in Antiquity, Western scholars and scientists did not usually write in Greek but kept using Latin, which had by then become well adapted to the task, although there are still occasional complaints about its poverty (like that by Kepler, quoted above). Of course, Greek influence continues to this day in the vernacular languages of science (see chap. 23). Figure 7 above tried to summarise these phases of Greek influence on Latin over time.

First attempts in Antiquity to take over science from Greek (by authors from Cicero to Boethius) did not initiate a large-scale Latin science movement that would (using Galen's simile) begin to walk on two legs. This happened only in the twelfth century, and it produced the scholastic Latin described above (chap. 11): it strongly relied on the logical structuring of texts, and on suffixation and relative clauses to cope with Greek nominalised phrases using the article and compounds. Puelma (1980: 146) points out some of the main difficulties Latin had to face when beginning to express Greek thought:

Die Bedeutung dieses hochgesteckten Zieles Ciceros kann man ermessen, wenn man bedenkt, dass in der lateinischen Sprache nicht nur fast die gesamte wissenschaftliche, abstrahierende Terminologie fehlte, sondern auch eine Reihe gerade jener Elemente der Wort- und Satzbildung in ihr nur schwach oder gar nicht vorhanden waren, die für die Geschmeidigkeit und Leistungsfähigkeit der griechischen Philosophensprache Voraussetzung waren, so die Leichtigkeit der Präfix- und Suffixbildungen, die unerschöpflichen Möglichkeiten der Wortkomposition, die reichhaltigen Partizipialkonstruktionen, die so gut wie unbeschränkte Fä-

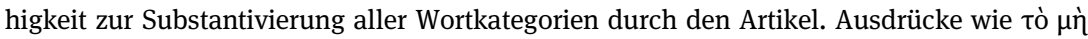

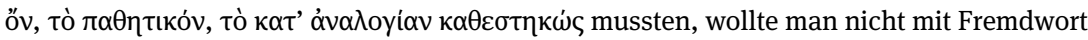
oder unverständlich wirkenden Wort-für-Wort-Wiedergaben vorliebnehmen, in mühsamer Versuchsarbeit durch Annäherungskonstruktionen des Lateinischen ersetzt werden, so dass das sprachliche usitatum gewahrt und doch das sachliche novum deutlich und verständlich wahrgenommen wurde. ${ }^{45}$

'The importance of this ambitious goal of Cicero can be appreciated when one considers that Latin not only lacked almost the entire scientific, abstracting terminology, but also that a number of precisely those elements of word- and sentence-formation that were prerequisites for the malleableness and effectiveness of the Greek philosophical language were only weakly present in it or not at all, such as the ease of forming words with prefixes and suffixes, the inexhaustible possibilities of word composition, the rich participial constructions, and the almost unlimited ability to substantivise all word categories using the article. Ex-

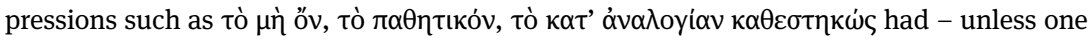
wanted to settle for a foreign word or incomprehensible word-for-word renderings - to be replaced by approximate constructions in Latin in a laborious process of experimentation so

45 Poncelet (1957: 51), who studied Cicero's translation of the Timaeus, saw a further domain in which Latin could hardly adapt to Greek thought: the usage of prepositions, which are more ambiguous in Latin. 
that the linguistic usitatum was preserved and yet the factual novum was perceived clearly and comprehensibly.'

Translators who were not concerned about usitatum could translate into a Latin very close to the Greek original, as many twelfth-century translators, such as James of Venice, did (chap. 10 §6) using the verbum de verbo technique. For instance, quod or hic could be used as an article surrogate, but it can and would be argued that the result is neither Greek nor Latin. ${ }^{46} \mathrm{~A}$ translation must not only be possible in abstracto; it must also be acceptable and comprehensible to its audience. The following sections look at what would seem to be the three most important Greek structures for scientific expression and how they could or could not be rendered in Latin.

\section{The article}

\$6 The lack of articles may be Latin's most inconvenient feature for the expression of scientific Greek thought. ${ }^{47}$ It will make sense to first provide some background about what articles are and what can be done with them. The implications and attempts to remedy the situation by Latin writers are then discussed. Himmelmann studied articles in various languages. He found that demonstrative pronouns apparently occur in all languages, but definite articles only in a few (1997: 1). All Western European languages acquired articles through grammaticalisation from demonstratives, through erosion and contextual expansion (2). Quite in general, articles arise from adnominal, grammaticalised local deictics (6), which, however,

46 As e.g. the Renaissance translator Leonardo Bruni did (chap. 12 §).

47 Similarly Wieland: 'Ermöglicht wird diese Thematisierung der Funktionalbegriffe durch die auf den ersten Blick recht trivial erscheinende Tatsache, dass die griechische Sprache den bestimmten Artikel kennt. Daher ist es der griechischen Sprache leicht möglich - was in der lateinischen, wie Ciceros Übersetzungen zeigen, nur mit großer Mühe geht -, außer Dingen im engeren Sinne nicht nur Eigenschaften, sondern auch konjunktionale, adverbiale, pronomiale und vor allem präpositionale Bildungen, ja sogar ganze Sätze zum Subjekt von Aussagen zu machen und danach Termini zu prägen. Von dieser Möglichkeit hat Aristoteles wie niemand vor ihm Gebrauch gemacht' ('This thematisation of the functional terms is made possible by the fact, which at first glance seems quite trivial, that the Greek language has the definite article. Therefore, it is easily possible for the Greek language - in Latin, as Cicero's translations show, this is only possible with great difficulty - to turn into the subject of statements, in addition to things in the narrower sense, not only properties but also conjunctional, adverbial, pronomial, and above all prepositional formations, even entire sentences, and then to coin them as technical terms. Aristotle made use of this possibility like nobody before him'; 1970: 175). Examples are discussed on the following pages, basically tò + non-noun: tò + letter, tò + quotation, tò + adjectives (like

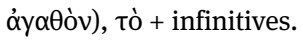


may acquire very different functions from those of a definite article (Himmelmann presents examples from South East Asian languages). Such articles seem to be emerging structures that are rather unstable within languages..$^{48}$ Joseph H. Greenberg (1978) formulated a 'cycle of the definite article': beginning with a demonstrative, through a stage of a grammaticalised article, to a mere noun marker, and then to zero. Knowing that articles are not very common and not very stable, it is a very conspicuous fact that all major Western and Central European languages have two articles at their disposal today, one indefinite ('a', un, ein, etc.) and one

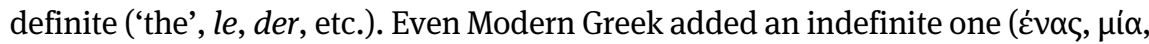
$\left.\varepsilon^{\prime} v \alpha\right)$ to its repertoire. ${ }^{49}$ We can speak of an article Sprachbund in Western Europe. The definite articles grew (as expected) out of demonstrative pronouns; the indefinite article tends to be a form of the word for one ('one', un, eins), thus showing its nature of having to do with one object out of a potential multitude.

There are subtle differences between the articles of these different European languages, and it is impossible to define one sole rôle these articles share. Thus, it will be best to identify various nuances the article can add to a given word or phrase. The Soviet scholar Admoni (1972: 172) attempted exactly this for the German article, whose functions are according to him that (i) it provides information about a noun's category of being countable or not; (ii) it can individualise or generalise a noun; or (iii) it can show the definiteness or lack thereof of something, thus differentiating facts already known from such that are not. ${ }^{50}$ It would seem that at least two more functions should be added to the list: the article can function (iv) to determine the case and number of indeclinable words, such as foreign words or symbols in German (e.g. 'die Exponentialfunktion des $2^{x}$, where English would use a preposition: 'the exponential function of $2^{x}$ ); $;^{51}$ and (v) as a nounphrase marker, although contemporary German tends to see this as stylistically ugly when it gets too long (e.g. 'das Heute-morgen-spät-nach-Hause-Kommen', '^the coming home late this morning', which nonetheless remains a grammatical

48 '[...] besteht die zentrale Hypothese dieses Buches darin, dass syntaktische Struktur ein emergentes Phänomen ist, also nicht von einem universalen Strukturschema für nominale Ausdrücke auszugehen ist' ' '[...] the central hypothesis of this book is that syntactic structure is an emergent phenomenon, i.e. a universal structural scheme for nominal expressions cannot be assumed'; Himmelmann 1997: 11).

49 Besides Latin, the exception to this rule is Russian (and many other Slavonic languages), which to this day does not have any type of article.

50 Similar lists can be found in standard works such as Vater (2002): definiteness (anaphora, deixis, larger situation), quantification, genericness. The most important function in our context, that of marking noun phrases, is not mentioned there either.

51 This is also possible in German; the difference is the same as using or not using an article (e.g. determination). 
and understandable German utterance). This is the main point in our context: the article can turn any utterance into a new functional 'noun' that can be used in any function in the sentence or can be referred to as a single entity. This function exists in English, which can for instance say 'the reviewers' hostile criticising of the play, ${ }^{52}$ a noun phrase that can in turn be inserted into many kinds of clauses as if the entire construction were but one single noun. But Greek and German can go much further than English with such constructions, as the following example from Pseudo-Dionysius the Areopagite (De mystica theologia 1.3, ed. Heil \& Ritter, p. 143) shows. He is speaking of the first cause:

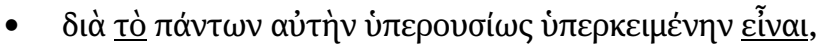

- $\quad \underline{h o c}$ omnibus eam supersubstantialiter superjacentem esse (trans. Hilduin, ninth century),

- ob suam super omnia sublimitatem et praestantiam (trans. Halloix, seventeenth century), ${ }^{53}$

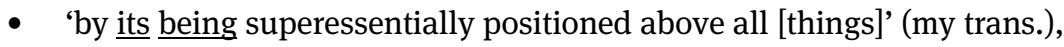

- 'durch $\underline{\mathrm{ihr}}$ gegenüber allem überseinderweise darüberliegend Sein' (my trans.).

German and English here replace the article with a possessive pronoun which takes over its function. ${ }^{54}$ But Latin cannot imitate such constructions. Hilduin tries to use hoc as an article substitute, which, however, is a solution that was never accepted by Latin language purists. The normal solution Latin will use in such cases is well illustrated by Pierre Halloix: suffixes are used to nominalise non-nouns. Above (chap. $12 \S 1$ ), it has been seen that this is a major point for which scholasticism was chided by humanists. English and even more so German can emulate the Greek construction with their articles. ${ }^{55}$ Without an article, Latin

52 Example from the section on nominalisation in Quirk et al. (1985: §17.51, p. 1289).

53 Both Latin translations are from Chevallier's edition, vol. 2, p. 573.

54 Nouns with possessive pronouns are automatically determined.

55 But the English article can nominalise much less than its Greek, French, or German counterparts: le barbu or der Bärtige has to be rendered as 'the bearded man' or, at least 'the bearded one', as the English article cannot be used with adjectives or infinitives, although it can be with -ingforms (e.g. 'the making'). Latin could say barbatus to mean the same thing, but this participle may not be easily discerned as a noun in the sentence, and besides the reader cannot know whether the topic is a specific bearded man ('the') or some random one ('a'). Another possible solution to this problem, which Latin would not choose in this case, is using suffixes to make things clear ( ${ }^{*}$ barbator); this is what the Slavonic languages tend to do in such circumstances, such as Russian бородатый ('bearded', adjective) vs бородач ('bearded man', der Bärtige, with nominalising suffix). Example from Birkenmaier (1979: 145). 
was reluctant to use even the infinitive as a noun, as this tends to sound vulgar. Thus Petronius (Satyricon 52.3, ed. Ernout, p. 49) does this mockingly: ${ }^{56}$

meum enim intelligere nulla pecunia uendo.

'I sell my understanding for no amount of money.'

Nonetheless, this function becomes much more common in scholasticism; for instance, in Thomas Aquinas, especially words such as esse or velle are often used as nouns. Incidentally, Aquinas also noted the absence of the nominalising article in comparison to Greek and the Romance languages (in Expositio Peryermeneias lib. 1, lectio 5, Leonina edition, vol 1, p. 26):

Set hoc uidetur habere instanciam in uerbis infinitiui modi, que interdum ponuntur ex parte subiecti, ut cum dicitur: 'ambulare est moueri'.

Set dicendum est quod uerba infinitiui modi, quando in subiecto ponuntur, habent uim nominis; unde et in Greco et in uulgari Latina locutione suscipiunt additionem articulorum sicut et nomina.

'But this seems to have force in verbs in the infinitive, which are sometimes used as subjects. For instance when one says "walking is moving".

But it has to be said that verbs in the infinitive used as subjects have the force of nouns: thus, in Greek and Romance they have an article added to them like nouns.'

Now, it is obviously perfectly possible to do science in a language without articles, as Latin and Russian demonstrate, but this lack does bring limitations with it. This obstacle was never fully overcome in Latin; the solutions proposed over the centuries were all more or less emphatically rejected by stylists, who found them unacceptably ugly, although some of them would have worked well enough. We briefly summarise the three main ones. ${ }^{57}$

(i) The use of the Greek article as a loanword in Latin. This is occasionally done already in Antiquity, for example in Donatus' commentary on Terence: ${ }^{58}$

Tò istuc, exceptive dictum, [...].

'The [word] istuc, said by means of stressing an exception, [...].'

This solution has the additional advantage that this article may be declined. Technical texts in early modern times, by authors who were not language purists, returned to this rather radical solution not infrequently. An example is the Grammatica arabica by Thomas Erpenius (Leidae, 1613, p. 6):

56 See Risch (1984: 27).

57 See Stotz (1996-2004: IX, §37.11 =vol. 4, p. 290).

58 From Hecyra line 608, ed. Marouzeau, vol. 3, p. 67; see TLL (s.v. exceptivus). 
[...] nisi quod Mauri Kaf uno puncto superne insigniunt, hoc modo,$\tau \tilde{\omega}$ Fe vero, ut ab illo differat, suum apicem subjiciunt, in hunc modum ب: qua quidem nota certe dignosces codices eorum ab iis, qui in Oriente exarati sunt.

'[...] except that the Moors mark the Qaf with only one upper point, viz. like this: $\mathbf{3}$; for the Fa, conversely, in order that it differ from it, they write its point below, like this: . By which sign you can distinguish their codices from those that were penned in the Orient.'

The $\tau \tilde{\varphi}$ Fe shows the reader that the Arabic letter-name ' $\mathrm{Fa}$ ' is here taken as a dative which goes with subicio. Such a solution, however, can only pass as not too awkward in times when Greek is widely known among readers and highly esteemed (both being the case in early modern times). Another user of this article is the lexicographer Goclenius. In his lexicon, we frequently meet formulations such as $\tau$ ò esse et $\tau o ̀ ~ o p e r a r i .{ }^{59}$ Even in the twentieth century, some Jesuits used this device. Karl Frank, for example, writes 'lex toũ fieri (Satz des Geschehens)' (Philosophia naturalis 1.2.1.1, p. 50), apparently feeling that without the German equivalent the phrase might still be unclear. But this was considered a 'barbarism' by language purists. ${ }^{60}$

(ii) An indeclinable article li (also spelled $l y$ ) based on the French article was occasionally used by the twelfth-century translators and at scholastic universities. ${ }^{61}$ Thomas Aquinas used ly 345 times in his three main works, which is not much considering that they contain nearly 3.5 million words. He uses it exclusively to single out words as we would do today using quotes, such as ly pater ('the word "father"). ${ }^{62}$ The Pseudo-Bedan treatise Sententiae philosophicae collectae ex Aristotele atque Cicerone (PL 90) of unknown age (but hardly older than twelfth century) also makes use of this article very frequently. Petrus Cantor (d. 1192) uses it occasionally (in Verbum abbreviatum PL 205: 38 occurrences). This article was taken over as such from Old French, without inflection. Occasionally, it also appears as the more typically French $l e^{63}$ or in an apparently southern Italian form $l u .^{64}$ In later times, it can also be used to cover more than one word, but

59 Conciliator philosophiae, p. 553, from 1609.

60 e.g. Krebs (1843: 90).

61 Stotz (1996-2004: IX, §37.12 =vol. 4, p. 290).

62 The instances can be viewed in Corpus Corporum by searching the Aquinas corpus for $l y$.

63 Moerbeke’s translation of Aristotle’s Poetica, ed. Minio Paluello, p. 44: le facere. See Tarán \& Gutas's edition, pp. 137-139.

64 e.g. here and there in Iohannes Alexandrinus, Commentaria in sextum librum Hippocratis Epidemiarum, ed. Pritchet, pp. 138, 192, 408, 427, 434, sometimes in the text, sometimes in the apparatus. This text also and more often uses hoc as an article surrogate (see point (iii) below). Iohannes apparently flourished in the seventh century; thus, this Parisian article must be a later addition and should never stand in his main text; indeed, the best manuscript, E, usually does not have it. All known manuscripts are late (fourteenth to fifteenth century). They are predominantly 
still in a function for which quotation marks would now be used, for instance in Federicus Chrysogonus (1472-1538), Speculum astronomicum 4.3:

Magnitudo enim est genus ad lineam et differentia est ly sine latitudine.

'Magnitude is the genus for the line and the "without dimension" is the differentia.'

Thus, $l y$ is not a full article but rather a marker of words like our quotes or Sanskrit's word iti (literally 'so') which has a similar function.

(iii) Another possibility for forging a full article in Latin is to use demonstratives such as ille, ipse, ${ }^{65}$ quod, or hoc. We have seen above that this is the expected way for a language to acquire an article. The first of these led to the formation of almost all Romance articles among speakers of Vulgar Latin (Fr. le, It. il, Span. el, Port. $o$, Rom. -ul, etc.), the second to the Sardinian one $s u$; we have met the third and fourth options above (chap. $21 \S 5$ and at the beginning of the present $\S$ ) but the phenomenon never made it into 'good' Latin, as it was clearly perceived as vulgar. Mediaeval folkloric texts such as the Vita Amici et Amelii do not have such scruples and often use it, sometimes also an indefinite article quidam (often preceding its noun: quidam homo = un homme) or unus in the same function. Descriptive texts about foreign parts, such as William of Rubruck's Itinerarium, a description of his journey to the Mongols in the thirteenth century, use this device to render indeclinable words declinable, for instance Moal ('Mongol'). In the book, there are nine instances of ipse in various cases followed by Moal and one with ille. ${ }^{66}$ The same problem occurred with indeclinable biblical names. Lambertus de Monte (ca. 1500), for instance, wrote ipsi Iaphet to mark the dative case (Quaestio de salvatione Aristotelis concl., line 162, ed. Roelli, p. 152). The mathematician Carl Friedrich Gauß in the nineteenth century still sticks to ipse in order to render numbers declinable (e.g. ipsius $x$ 'of the number $\left.x^{3}\right){ }^{67}$ This rather inconspicuous article surrogate is quite often used in this function, but to my knowledge it is not used to nominalise non-nouns, such as *ipsum velle for '*the wanting' (das Wollen, le vouloir). ${ }^{68}$ The resulting 'articles' needed getting used to, but apparently

from southern Italy. Sicilian still uses today $l u / l a$ as definite article, although sometimes dropping the $l$.

65 Stotz (1996-2004: IX, §37.2-10 =vol. 4, pp. 288-290).

66 An example: quia vita ipsorum Moal et etiam tuinorum (chap. 26). The tuini are the Buddhists he met at the Mongol court. The phrase quia vita Moal et etiam tuinorum could be ambiguous. An alternative would have been to decline Moal and write, for example, Moalorum.

67 Often used in Disquisitiones arithmeticae, e.g. §9, vol. 1, p. 11: Sint f, g valores congrui ipsius $x$. 68 Corpus Corporum searches of the kind ipse/ille followed by INF have not produced clear cases; with adjectives - such as ipsum bonum - the Platonic 'idea of the Good' is intended in Latin (like in Greek aủtò tò óyäóv). 
Latin students did get used to these translations at the early universities (before the Renaissance). But in the long run, these pseudo-articles too were rather shunned by educated authors because they, too, seemed vulgar. Stylistically sensitive authors, therefore, had to live without an article.

\section{Compounds and nova verba}

§7 Quirk et al. (1985: §17.123, p. 1350) state that compounds and noun phrases are the most typical features of scientific English. ${ }^{69}$ In contrast, the importance of newly formed features in Greek science seems to depend strongly on the science in question. In philosophical and theoretical scientific language, compounds have not been found to be very common (see chap. 21): a detailed study of those in Latin translations of book II of Aristotle's Physica revealed most of the compounds to be words formed with preverbs, which can easily be imitated by Latin. ${ }^{70}$ True compounds - those containing at least two roots - are rare in the Greek text as well. But matters are different in other fields, such as botany or medicine, where many new res stand in need of names. In Greek these are often true compounds. In Latin they are often just taken over as loanwords by Latin translators. ${ }^{71}$ Although Celsus, the first Latin medical writer whose work survives (see chap. 21), strives to say things in Latin, this is soon lost among his colleagues. Here is a quite typical example from Caelius Aurelianus (Tardae passiones I.115, ed. Drabkin, p. 448; fifth century):

Declinante passione cerotariis atque malagmatis simplicibus utendum, ut est diachylon.

'When the disease diminishes, wax plasters and simple emolients [ $\mu \alpha \dot{\lambda} \alpha \gamma \mu \alpha]$ are to be used, such as diachylon $[\delta ı \grave{\alpha} \chi \nu \lambda \tilde{\omega} v] .{ }^{72}$

Greek words are very common; they may have sounded as 'professional' to patients as Latin-Greek ones do today. Often they are compounds. In theory, Latin, as an Indo-European language, should be able to form new compounds easily. But Latin compounds tended to sound odd to the educated Roman, according to Quintilian (Institutio oratoria I.5.70, ed. Rahn, vol. 1, p. 86):

69 They offer an example sentence: 'At the mouth of the respiratory tube is a series of velar tentacles, corresponding exactly in position to those of amphioxus, and serving to separate the mouth and oesophagus from the respiratory tube while the lampre is feeding' (italics in original).

70 See Roelli (2014a) and the online list at http://mlat.uzh.ch/texts/compounds.html.

71 See Panagl (1986). On Greek words in Latin, see Biville (2002).

72 An unidentified medicine; Drabkin renders 'plaster of juices'. 
Sed res tota magis Graecos decet, nobis minus succedit, nec id fieri natura puto, sed alienis fa-

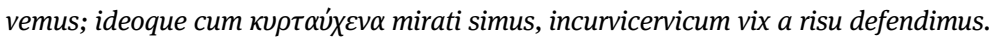

'But this matter [compounds] is more adequate in Greek; it occurs more rarely with us, but I do not believe that this is by nature. Instead, we prefer foreign things: thus we applaud [the

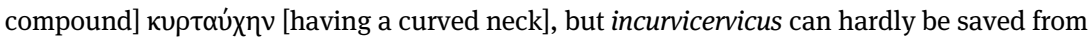
ridicule.'

Quintilian provides examples of Latin compounds in the same chapter. In VIII.3 he addresses Latin's reluctance to form new words in general, be it by compounding, suffixation, or other means. ${ }^{73}$ He rightly concludes that Latin should not shun such new words altogether (VIII.3.33, ed. Rahn, vol. 2, p. 162) as the purists would have it. Nonetheless, Latin authors tend to be very cautious when introducing new compounds; for example, Aulus Gellius tries inlatabile (Noctes Atticae I.20.9, ed. Marache, vol. 1, p. 64) for Euclid's ( $\mu \tilde{n} \kappa o \varsigma) ~ \alpha ่ \pi \lambda \alpha \tau$ ć ('without breadth'), which defines a line in geometry, introduced with a cautious quod exprimere uno Latino verbo non queas, nisi audeas dicere inlatabile ('which you cannot express in Latin in a single word, unless you dare to say inlatabile'). Indeed, the word inlatabile never seems to have been used again. ${ }^{74}$ Often new words were made to sound less harsh by adding ut ita dicam, si licet dicere, or similar to gain the reader's benevolence. ${ }^{75}$ For instance, Seneca invents in his Naturales quaestiones (III.23, ed. Oltramare, vol.1, p. 140) the harmless-looking word supernatare (ut ita dicam supernatantes) to describe water that wells up or literally

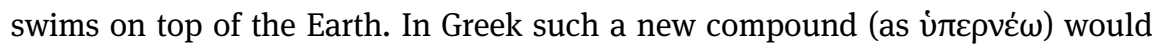
have been totally inconspicuous. Latin poets were somewhat freer to create new words; for example, Statius (Silvae III.2, line 47, ed. Frère, p. 107) uses supernatare without apology. Nonetheless, even in poetry a rather limited number of types of compounds is common: especially those in -fer, - ger, -ficus, - cola $^{76}$ Late Antiquity and the Middle Ages will also use neologisms more freely, especially in medicine and scholasticism. PL has, for instance, 132 instances of supernatare. ${ }^{77}$

73 Institutio oratoria VIII.3.30, ed. Rahn, vol. 2, p. 162: Fingere, ut primo libro dixi, Graecis magis concessum est, qui sonis etiam quibusdam et adfectibus non dubitaverunt nomina aptare, non alia libertate quam qua illi primi homines rebus appellationes dederunt ('The coining of words, as I stated in the first book, is more permissible to the Greeks, for the Greeks did not hesitate to accommodate words to certain sounds and emotions, using the same liberty by which the first human beings gave names to things').

74 Only this one hit in Corpus Corporum. Lindner (2002: 161) argues that Latin was in fact quite 'kompositionsfreudig', despite Latin authors' claims to the contrary. For authors aware of Latin style, this is certainly not the case.

75 See Hélin 1960 about these 'apologies'.

76 See the data in Lindner (2002). 
But even in the Middle Ages, true compounds are only rarely coined. Most of the time, new words are formed using prefixes, or even more often suffixes (see §8). A safer option for Latin writers has to a greater or lesser extent always been to introduce Greek words into their texts as loanwords. This is what the humanists would rather do, but it is also very common in medical writers such as Caelius Aurelianus, as we have seen. Some mediaeval authors who had access to Greek scientific or scholarly prose tried to use more Latin compounding, such as John Scotus Eriugena (see chap. 9 §11) or Liutprand of Cremona (ca. 920-972), ${ }^{78}$ but they had little success. The discussion of the extent to which writers may forge new words continued throughout Latin's lifespan, but the consensus remained rather on the cautious side.

Today, the language of science that is most fond of using compounds is certainly German. It can even produce compounds consisting of exclusively GraecoLatin constituents, such as kommunikationssysteminterne Konstrukte (communica-

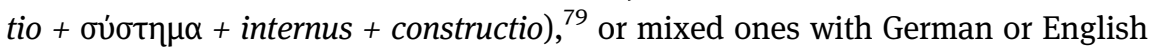
constituents (the latter being especially en vogue these days, although disliked by conservatives), for instance hybrider Imitationscluster. ${ }^{80}$ It would seem that compounds are very useful in scientific language, but their use can be overdone and they can be used to produce utterances with little palpable meaning, something that some German writers were and are very good at. In English, compounding is also more common than in Latin, though compounds are less conspicuous as they are usually not written as one word; they tend to be treated as a type of noun phrase. ${ }^{81}$

\section{Suffixation}

\$8 The lack of an article and reluctance to compound can be compensated by subordinate clauses (especially relative ones). But they can easily become too much to handle for the reader. To a certain extent, they can also be alleviated by suffixation. ${ }^{82}$ Above (chap. 18 §2), we have seen that suffixes become significantly more common in the Middle Ages. Some of the authors in the general scientific corpus,

77 This observation may also be explained in terms of Stotz's Normenentfaltung: once someone like Seneca made the first step, later writers lost their restraint regarding a word.

78 On his Greek, see Koder (1980). It seems to have been more spoken than literary Greek.

79 From Luhmann (1990: 24).

80 Oral utterance at a conference I attended. I am not sure this utterance made any sense at all. 81 e.g. Quirk et al. (1985: \$17.104-108, pp. 1330-1334). Compare English 'garden fence' to German Gartenzaun.

82 For more details on some of the suffixes in Thomas Aquinas, see Roelli (2013). 
especially scholastic ones, use them much more frequently than average. This is especially true for adjective suffixes, but also for some noun suffixes, -tio being the most conspicuous case. Despite large standard deviations between authors, the following suffixes can be safely said to be more common in the Middle Ages than in Antiquity (see table 9 above): -alis, -bilis, -inus; -itia, -ntia, -tas, -tio. Suffixation is rightly seen as typical for scholastic Latin. In Roelli (2013), I searched entries in the Schütz lexicon for Thomas Aquinas that never occur in classical or early mediaeval Latin ${ }^{83}$ or PL. Excluding Greek words and regularly formed adverbs from attested adjectives, the following 115 words remained (the suffixes studied in chap. 18 are underlined):

actuare, agibilis, amativus, appetibilitas, argumentativus, assumptibilis, campsorius, causali$\underline{\text { tas, }}$ certitudinalis, cognoscibilitas, cognoscitivus, cointelligere, communicabilitas, concausa, condicionalis, condicionatus, condignativus, condignitas, condividere, connaturalitas, consiliabilis, consiliativus, conspecialis, constrictivus, contiguatio, contrapassio, contrapassum, contumeliatio, contumeliativus, deratiocinari, deteriorativus, difformiter, dimensivus, dinotica, discontinuare, discontinuatio, discontinuus, disputativus, divinativus, doctrinatio, executi-

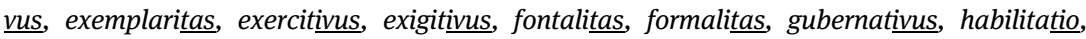
ideare, ideatio, immediatio, immutativus, impotentialitas, improbabilitas, improcessibilis, incommunicabilitas, incompossibilis, incorporeitas, indisciplinabilis, individuare, individuatio, infiguratio, iniustificatio, inquisitive, intimativus, inventivus, iudicativus, iudicatorium, laesi-

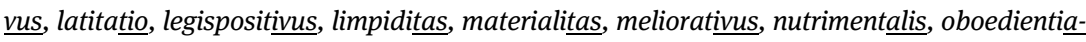

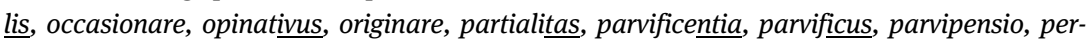
vietas, postpraedicamentum, potentialitas, praeacceptio, praeconsiliatus, praedeterminatio, praevolatio, principativus, protestativus, quidditativus, regitivus, reminiscitivus, retributivus, satisfactivus, situalis, speculabilis, sperativus, subactivus, subalternare, subauctoritas, substantificator, substantivare, supersubstantialitas, tactivus, totalus, transcorporatio, unibilitas, unitive, univocare, velleitas, volibilis, voluntabilis.

Practically all non-verbs in this list are formed with some of the mentioned suffixes; prefixes are also very common. This practice is, indeed, one of the most typical features of scholastic Latin. It was strongly rebuked by humanists who wanted to return to 'pure' Latinity. They especially chided scholastic suffix constructions such as entitas or perseitas, as we have seen Valla do (chap. 12 \$1). Despite their criticism, suffixation worked well to translate, for instance, an otherwise untranslatable tò $\kappa \alpha \theta$ ' $\alpha$ ứó clearly and succinctly with perseitas.

83 The dictionaries by Georges and Niermeyer were used to exclude such words. 


\title{
Latin language engineering
}

\$9 Certainly, by language engineering Latin could have been adapted to Greek or other source languages much more strongly than what finally prevailed as scholastic and later academic Latin. The mystical author Marguerite Porete (d. 1310) can provide a glimpse what such a 'Latin' could have looked like also in the sciences. In this case, the source language is Old French, but a wish to emulate scholastic Latin can clearly be felt; in fact, the Latin text was translated from a French original (CCCM 69, pp. 400-403): ${ }^{84}$

\begin{abstract}
Modo est in esse sui primordialis esse, quod est suum esse. Et dimisit tria et fecit de duobus unum. Quando est illud unum? Illud unum est quando anima est resoluta in illam simplicem diuinitatem, quae est unum simplex esse expansae et dilatatae fruitionis in plano scire absque sentimento supra mentem. Illud simplex esse facit in anima ex caritate quicquid anima facit, quia uelle est simplex effectum.

'Now, in its [the soul's] being the primordial being is encountered, which is its true being. And it has left behind the three and made one out of two. ${ }^{85}$ When does this "one" happen? This oneness happens when the soul is resolved in that simple divinity that is simple oneness of pervasive and spread-out fruition in full consciousness, devoid of feeling, above thinking. By charity, this simple being makes the soul do whatever the soul does, as [in this state of mind] volition happens automatically.'
\end{abstract}

This language uses ille as a normal article (e.g. illud unum) and infinitives are often nominalised (illud simplex esse). This kind of Latin was, however, rejected by educated authors for being 'vulgar'. Latin did change at the scholastic universities, but not in such an extreme way. Scholastic Latin was a very successful form of Latin, but the humanists derided it and, concerning the features discussed in this chapter, were able to make scholars and scientists more cautious not to strain too far from 'Classical' Latin.

Latin thus had to go different ways, and one might wonder whether the different character of later Latin scientific language, compared to Greek, evolved to overcome these problems. Groups of terms could not so easily be turned into 'entities' using the article; instead, suffixation, logic, then mathematisation follow in Latin science, as is still the case in English-language science today. Easy compounding can also be seen as a negative point for scientific clarity, as we have seen for German examples: like the ablativus absolutus, Indo-European com-

84 The corresponding French text: 'Or est ceste Ame en l'estre de ce premier estre qui est son estre, et si a laissé trois, et a fait de deux ung. Mais quant est cest ung? Cest ung est, quant l'Ame est remise en celle simple Deité, qui est ung simple Estre d'espandue fruiction, en plain savoir, sans sentement, dessus la pensee. Ce simple Estre fait par charité en l'Ame quanque l'Ame fait, car le vouloir est simple devenu.'

85 The three are soul, world, God; the two are soul and God. 
pounds are underdetermined, as the possible relations between their constituents can be manifold. A Latin writer would more clearly but less succinctly speak of something like constructiones in systemate communicationis inhaerentes (ignoring semantic changes in the constituent parts) for what Luhmann put into two German words in the example above. Thus, a Latin writer has to declare the syntactic relations more explicitly than a German one. Latin's different and, compared to Greek, less versatile structure clearly produced something new, a scientific Latin, which, for instance, led to texts like Newton's with our present understanding of classical physics, where for example 'energy' has become a very different thing

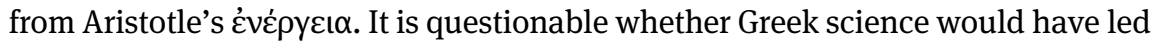
to science comparable to what we have today. Ultimately, it is the scholastic style that has prevailed in modern scientific writing: precision, not beauty; small vocabulary; and simple syntax are now all hallmarks of scientific English, at least in the natural sciences. A random modern example of the latter shows clear similarities (Doudna \& Charpentier 2014):

We review the history of CRISPR (clustered regularly interspaced palindromic repeat) biology from its initial discovery through the elucidation of the CRISPR-Cas9 enzyme mechanism, which has set the stage for remarkable developments using this technology to modify, regulate, or mark genomic loci in a wide variety of cells and organisms from all three domains of life. These results highlight a new era in which genomic manipulation is no longer a bottleneck to experiments, paving the way toward fundamental discoveries in biology, with applications in all branches of biotechnology, as well as strategies for human therapeutics.

Relative clauses and noun phrases are very frequent, as are -ing-forms. The technical terminology relies on the one hand on Graeco-Latin terms ('interspaced', 'palindromic', 'biotechnology', etc.), on the other on acronyms ('CRISPR', 'Cas9'). The standard formulations and the logical structure would be typical for a scholastic text as well. One might speak of a modern scientific koine with Greek roots and a scholastic trunk that is still thriving in modern English science.

These somewhat different approaches to scientific language in Greek (and similarly German) and in Latin (and similarly English) may have played their part in the development of, say, Anglo-Saxon analytical philosophy vs the classical German philosophers, or maybe even of typically English natural vs typically German human sciences. It would seem that Greek was good at both; it produced both a Euclid and an Aristotle. 


\section{Science as a Graeco-Latin Denkstil}

\$10 With all of this, it becomes clear that one can speak of a Greek scientific Denkstil that developed uniquely in classical and Hellenistic Greek times, and was then transformed into somewhat different but related Denkstile in Latin from scholasticism to the Scientific Revolution, from which our modern science descends organically. It would seem that both speculation (corresponding to criterion II, 'explanation') and technology (implicit in criterion III, 'testability') on their own are universals in highly organised cultures. Indeed, technology has tended to advance quite linearly in many parts of the world $;{ }^{86}$ individuals making up fanciful theories of everything abound in at least China and India besides ancient Greece, as we have seen. The Greek novum was to link these two things and use them like two legs to walk by moving them alternately (in Galen's simile): attempting to render discoveries and technological advances understandable or, conversely, attempting to make fancy theories systematically testable and also rejectable. The Greeks, and especially Aristotle and his school, sought step-by-step, formalised new approaches to understanding things based on observation and logical, formalised thought, and not on tradition or hearsay. And they founded schools of thought in many fields. This seems to have been the only independent time this happened in human history. ${ }^{87}$ It may not be an exaggeration to call science a Greek Denkstil. Whether this alone should warrant the name 'science' is, of course, a matter of definition, but this distinctive intellectual current from غंतl$\sigma \tau \eta \dot{\mu \eta}$ through ('ilm and) scientia to Wissenschaft and 'science' certainly warrants its own distinctive name, although each of these changes of linguistic medium also brought along some changes to the originally Greek Denkstil.

86 See e.g. Hägermann \& Schneider (1991) for 750 BC to AD 1000.

87 Störig (1965: 51) reached the same conclusion. 